\title{
Rectal Suppository Dosage Form
}

National Cancer Institute

\section{Source}

National Cancer Institute. Rectal Suppository Dosage Form. NCI Thesaurus. Code C68989.

A suppository intended for administration within the rectum. 